\title{
Prevalence of Torus Palatinus in Cappadocia Region Population of Turkey
}

\author{
Yildiray Sisman ${ }^{\mathrm{a}}$ \\ Elif Tarim Ertas ${ }^{b}$ \\ Cumali Gokce \\ Faruk Akgunlud
}

\section{ABSTRACT}

Objectives: The objectives of this study were to determine the prevalence, size, shape and location of the torus palatinus (TP) in dental outpatients in Cappadocia region of Turkey and to investigate the relationship between the findings in relation to age and gender.

Methods: The present study included 2660 patients, who attended the Department of Oral Diagnosis and Radiology in the Faculty of Dentistry at Erciyes University for their dental problems between December 2005 and May 2007. The presence or absence of TP was examined by clinical inspection and palpation.

Results: The prevalence of TP in our large sample was low (4.1\%) in comparison to other Turkish population. It was found to be significantly higher $(P<.001)$ in females $(5.7 \%)$ than in males $(1.8 \%)$. Most TP were found in flat shape (62.7\%), smaller than $2 \mathrm{~cm}(75.4 \%)$ and located at premolar-molar region $(66.4 \%)$.

Conclusions: This study indicated that the prevalence of TP in Turkish population was low. Our results showed a significant relationship between the occurrence of TP and gender. According to the literature, it was firstly showed that flat TP was the most common type in our large population. (Eur J Dent 2008;2:269-275)

Key words: Epidemiology; Torus palatinus; Prevalence; Shape; Gender; Size.

assistant Professor and Chair, Department of Oral Diagnosis and Radiology, Faculty of Dentistry, Erciyes University, Kayseri, Turkey.

b Research Assistant, Department of Oral Diagnosis and Radiology, Faculty of Dentistry, Erciyes University, Kayseri, Turkey.

Dr., Department of Endocrinology and Metabolism,

- Kayseri Training and Research Hospital, Kayseri, Turkey.

d Professor and Chair, Department of Oral Diagnosis and Radiology, Faculty of Dentistry, Selcuk University, Konya, Turkey.

- Corresponding author: Dr. Yildiray Sisman, Department of Oral Diagnosis and Radiology, Faculty of Dentistry, Erciyes University, 38039, Melikgazi, Kayseri, Turkey.

Phone: +90 3524374901 /29226 Fax: +90 3524380657

E-mail: drsismandyahoo.com

\section{INTRODUCTION}

Tori are nodular protuberances of mature bone, the exact designation of which depends on anatomic region. ${ }^{1}$ Torus palatinus (TP) is an exostosis of the hard palate localized along the median palatine suture, involving both the processi palatini and the os palatinum. It contains compact and cancellous bone and is formed by the hypertrophy of the spongy and oral compact layers, the nasal compact layer remain unchanged. ${ }^{2}$ It is generally accepted as an anatomical variation rather than a pathological condition. ${ }^{3}$ TP forms different shapes as flat, nodular, spindle and lobular (Figure 1) 4,5 and is often detected in young adults and middle-aged people..$^{6-8}$ TP is asymptomatic, grows slowly during 
the second and third decades of life and often goes unnoticed until middle age..$^{9-11}$ Although, TP is not pathologically significant, surgical removal is required if it causes chronic trauma or interfere with oral function or with the replacement of a denture base or framework. ${ }^{3}$

Although a large number of researches have tried to clarify the influence of genetic, ${ }^{8,9}$ environmental, ${ }^{7,12}$ nutritional, and climatologic factors, there is still no consensus on the etiology of TP.

The prevalence of TP ranges from 1.4 to $66.0 \%$ in different populations (Table 1), ${ }^{2-4,6-9,13-}$ 26 and it was reported between $20.9-45.4 \%$ in Turkish populations. ${ }^{19,22,26}$ It was also found that females have a higher prevalence of TP. 3,4,6,7,9,13$15,18,19,21,23,26,27$

The aims of this study were to determine the prevalence, size, shape and location of TP and to investigate the relationship between the findings in relation to age and gender in Cappadocia region population.

\section{MATERIALS AND METHODS}

A total of 2660 dental patients admitted to the Faculty of Dentistry, Erciyes University from Cappadocia region of Turkey. All the patients were examined by YS in terms of the presence of TP. The subjects were stratified into six age groups: 13-19, 20-29, 30-39, 40-49, 50-59 and 60 years and older. The examination of the TP was assessed by clinical inspection and palpation, performed by the same author. The patients who have questionable TP were not included in this study. For the diagnosis, TP was defined as a raised bony exostosis in the midline of the hard palate.

The maximum elevation of the outgrowth of TP,

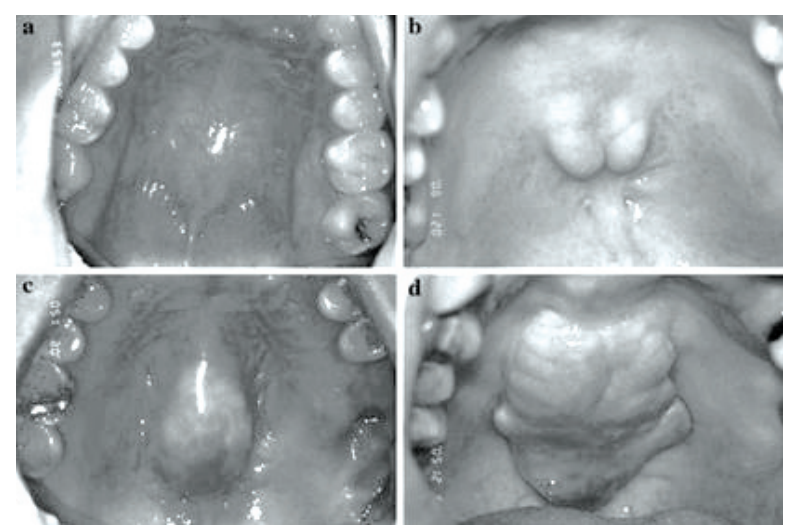

Figure 1 a-d. Taken from Jainkittivong et al, ${ }^{4}$ reprinted with the permission of Surgical Radiol Anatomy Journal. usually in consistent with width and length, ${ }^{3}$ was applied for the measurement of the size of TP and graded according to previous description ${ }^{21,26}$ as more or less than $2 \mathrm{~cm}$.

The shape of TP was classified as flat, nodular, spindle and lobular according to Jainkittivong et al. ${ }^{4}$ The locations of TP were classified as incisors, incisors-premolars, premolars-molars, molars, and incisors-premolars-molars.

\section{Statistical analysis}

The observed results were analyzed with SPSS 11.0 (Statistical package for social science Inc., Chicago, Illinois, USA). The chi-square test and t-test were used for group differences. $P$ values $<.05$ were considered statistically significant.

\section{RESULTS}

A total of 2660 subjects, 1576 were females and 1084 were males. The mean age was $33.0 \pm 15.1$ years with the ages ranging from 13 to 85 years. The mean age was $32.3 \pm 14.3$ years for females and $33.9 \pm 16.0$ years for males. There were 591 (22.2\%) subjects in the $13-19$ year, $693(26.0 \%)$ subjects in the 20-29 year, $508(19.1 \%)$ subjects in the 30-39 year, $437(16.4 \%)$ subjects in the $40-49$ year, 277 $(10.4 \%)$ subjects in the 50-59 year and 154 (5.8\%) subjects in the 60 years and older groups (Table 2).

Table 2 presents the distribution of TP in relation to age and gender. TP was recorded in $110(4.1 \%)$ of the 2660 individuals. It was found to be significantly higher $(P<.001)$ in females $(5.7 \%)$ than in males $(1.8 \%)$. The highest TP prevalence $(7.1 \%$ ) were in the oldest group ( 60 and older years age range). The prevalence of TP in females was higher than in males in terms of all age groups (except 13-19 years age group).

The distribution of TP size according to gender and age is shown in Table 3. Of the 110 TP cases the mostly $(75.4 \%)$ were smaller than $2 \mathrm{~cm}$. The age and gender differences in the distribution pattern of TP according to size were not statistically significant $(P>$.05).

Table 4 shows the location of TP on the hard palate in 110 subjects in relation to age. The most common TP was found at the premolar-molar region (66.4\%), followed by molars (15.4\%) and premolars regions $(13.6 \%)$. The less common locations were at incisor-premolar and incisor- 
premolar-molar regions $(4.5 \%)$.

Table 5 shows the distribution of TP according to shape in relation to gender. The most common shape of TP was flat (62.7\%). Other less common shapes of TP were spindle (36.3\%), nodular (0.9\%) and lobular $(0.0 \%)$. There was no significant difference found in TP shape between females and males ( $P>$.05).

\section{DISCUSSION}

There are many studies showing the TP prevalence ranges from 1.4 to $66.0 \%$ in different populations. ${ }^{2-4,6-9,13-26}$ A Turkish study ${ }^{22}$ was performed in 80 dry skulls, reported a high prevalence $(45.4 \%)$ of TP. In other study, ${ }^{26}$ the prevalence of TP was $30.9 \%$ in 1943 school children (5-15 years old). Cagirankaya et al ${ }^{19}$ pointed out that the prevalence of TP was $20.9 \%$ in consecutive 253 subjects (17-49 years old). According to our knowledge, this is the most detailed study in terms of the subject number $(n=2660)$ and the age range (13-85 years old) investigating TP prevalence in Turkish population.

The TP prevalence in this study $(4.1 \%)$ was lower in comparison to most of the other studies. ${ }^{2-}$ 4,6-9,13-17,19-24,26 The same low prevalence (3.9\%) was found by Bruce et $\mathrm{al}^{18}$ in 926 dental patients in the Ghanaian community. It was suggested that

Table 1. Comparison of findings of TP in various populations.

\begin{tabular}{|c|c|c|c|c|c|}
\hline $\begin{array}{l}\text { Year of } \\
\text { Publication }\end{array}$ & Population & $\begin{array}{c}\text { Sample } \\
\text { Size }\end{array}$ & Females (\%) & Males (\%) & $\begin{array}{c}\text { Prevalence } \\
(\%)\end{array}$ \\
\hline 1950 & Eskimos $^{3}$, a & - & - & - & 66.0 \\
\hline 1953 & United States ${ }^{24}$ & 2478 & - & _- & $20, .9$ \\
\hline 1966 & Yugoslavian² & _ & - & _ & 49.7 \\
\hline 1977 & Brazilian Indian ${ }^{17}$ & 200 & - & - & 10.0 \\
\hline 1984 & Singapore ${ }^{20}$ & - & 48.0 & 48.0 & 48.0 \\
\hline 1985 & Icelandic,South-Thingeyjarsysla ${ }^{16}$ & 763 & - & _ & 33.3 \\
\hline 1985 & Icelandic,North-Thingeyjarsysla ${ }^{16}$ & 213 & - & - & 14.6 \\
\hline 1987 & Saudi Arabia 25 & 1932 & - & - & 1.4 \\
\hline 1988 & Germans $^{8}$ & 1317 & - & - & 13.5 \\
\hline 1992 & Norway, Osla area ${ }^{7}$ & 5000 & $11, .2$ & 6.7 & 9.2 \\
\hline 1994 & Norway, Lofoten ${ }^{6}$ & 1181 & 43.4 & 32.7 & 38.2 \\
\hline 1994 & Norway, Gudbrandsdalen ${ }^{6}$ & 829 & 39.8 & 23.7 & 32.7 \\
\hline 1996 & |sraet ${ }^{21}$ & 1002 & 24.9 & 16.4 & 21.0 \\
\hline 1998 & Israel ${ }^{9}$ & 168 & 39.3 & 38 & 38.7 \\
\hline 1999 & Southern Thailand ${ }^{23}$ & 609 & 69.9 & 30.1 & 61.7 \\
\hline 1999 & Turkish 22 , a & 86 & - & - & 45.4 \\
\hline 2001 & African ${ }^{15}$ & 367 & 6.7 & 5.5 & 6.2 \\
\hline 2001 & West Indies ${ }^{15}$ & 212 & 7.9 & 4.7 & 6.6 \\
\hline 2002 & Thai $^{13}$ & 1200 & 67.3 & 48.8 & 58.1 \\
\hline 2004 & Ghanaian community ${ }^{18}$ & 926 & 5.2 & 2.2 & 3.9 \\
\hline 2004 & Turkish $^{19}$ & 253 & 28.2 & 6.0 & 20.9 \\
\hline 2005 & Turkish $^{26}$ & 1943 & 34.3 & 28.1 & 30.9 \\
\hline 2006 & Jordan $^{14}$ & 338 & 47 & 14 & 29.8 \\
\hline 2007 & Thail $^{4}$ & 1520 & 70.5 & 48.8 & 60.5 \\
\hline 2007 & Turkish (Present Study) & 2660 & 5.7 & 1.8 & 4.1 \\
\hline
\end{tabular}

a: Skulls 
dietary and ethnic factors may be important in this study. However, it was showed that there is a high prevalence of TP in other studies such as $21.0 \%$ in the young and adult population of Israelis, ${ }^{21}$ and in $20.9 \%$ of the United States population ${ }^{24}$ and in the Norway study (32.7\%). ${ }^{6}$ It was thought that environmental, genetic and functional factors are important for these prevalences. A less TP prevalence was found at Gizan region, Saudi Arabia (1.4\%). ${ }^{25}$ This study may reveal that racial differences are much more important for the prevalence.

In Turkish population, Yildiz et al ${ }^{26}$ investigated TP prevalence in 1943 school children and showed a higher prevalence $(30.9 \%)$ in comparison to the present study. All the school children were 5-15 years old, but our patients were 13-85 years old. The number of our subjects (2660) is higher than that study. In the other study, ${ }^{19}$ it was showed that the prevalence of TP was $20.9 \%$ in consecutive 253 subjects (17-49 years old). All these reports including our study were performed in the different regions and populations of Turkey. It may suggest that these prevalence differences may be due to age, regional and dietary factors.

These different prevalences in different populations may be due to ethnicity. It was reported that among similar ethnic groups living in different areas, ${ }^{6,16}$ or different ethnic groups living in same areas ${ }^{21,28}$ have various prevalences of TP. The formation of TP has been attributed to various factors by different authors. A huge number of investigators have evaluated the effects of environmental, ${ }^{7,12}$ and genetic factors $5^{8,9}$ including masticatory stress, ${ }^{7,8,23}$ and nutritional ${ }^{6}$ factors. The prevalence of TP within the same race reported by different authors varies greatly (Table 1). The inconsistent results of various authors possibly are due to the difference of the number of subjects, different geographic location, and standards.

Dietary factors may have a role for the tori prevalence. Eggen and Natvig ${ }^{29}$ investigated the influences of nutrients in the etiology of tori. It was suggested that saltwater fish consumption in Norway possibly supplies higher levels of polyunsaturated fatty acids and Vitamin D which is involved in bone growth and this may increase the prevalence of tori. Gorsky et $\mathrm{al}^{9}$ investigated the inheritance of TP by segregation analysis. Their results suggested that TP is and autosomal dominant triat. Belsky et $\mathrm{al}^{30}$ showed that the presence and especially the size of TP is correlated with increased bone mineral density. High bone mass may be associated with a gene mutation. Genetic factors may be the probable causes of the

Table 2. Prevalence of TP in relation to age and gender.

\begin{tabular}{|c|c|c|c|c|c|c|c|}
\hline \multirow{2}{*}{$\begin{array}{l}\text { Age groups } \\
\text { (years) }\end{array}$} & \multicolumn{2}{|c|}{ Females } & \multicolumn{2}{|c|}{ Males } & \multicolumn{2}{|c|}{ Total } & \multirow{2}{*}{$P$} \\
\hline & $\mathrm{n}(\%)$ & TP (\%) & $\mathrm{n}(\%)$ & TP (\%) & $\mathrm{n}(\%)$ & $\operatorname{TP}(\%)$ & \\
\hline $13-19$ & $338(21.4)$ & $6(1.8)$ & 253 (23.3) & $5(2.0)$ & $591(22.2)$ & $11(1.9)$ & \\
\hline $20-29$ & 441 (28.0) & $18(4.1)$ & 252 (23.2) & $5(2.0)$ & $693(26.0)$ & 23 (3.3) & \\
\hline $30-39$ & 311 (19.7) & $30(9.6)$ & 197 (18.2) & $3(1.5)$ & 508 (19.1) & 33 (6.5) & \\
\hline $40-49$ & $278(17.6)$ & $20(7.2)$ & $159(14.6)$ & $0(0.0)$ & 437 (16.4) & $20(4.6)$ & \\
\hline $50-59$ & $136(8.6)$ & 10 (7.3) & $141(13.0)$ & $2(1.4)$ & $277(10.4)$ & $12(4.3)$ & \\
\hline$\geq 60$ & $72(4.5)$ & $6(8.3)$ & 82 (7.5) & $5(6.1)$ & $154(5.8)$ & $11(7.1)$ & \\
\hline Total & 1576 (59.2) & 90 (5.7) & 1084 (40.8) & 20 (1.8) & $2660(100)$ & $110(4.1)$ & $* * *$ \\
\hline
\end{tabular}

Chi-square test: ${ }^{* * *}: \mathrm{P}<.001$

Table 3. Distribution of TP in relation to gender, size and age.

\begin{tabular}{ccccc}
\hline TP size & $\begin{array}{c}\text { Females }(\mathrm{n}=90) \\
\mathrm{n}(\%)\end{array}$ & $\begin{array}{c}\text { Males }(\mathrm{n}=20) \\
\mathrm{n}(\%)\end{array}$ & $\begin{array}{c}\text { Total }(\mathrm{n}=110) \\
\mathrm{n}(\%)\end{array}$ & $\begin{array}{c}\text { Age (years) } \\
\text { Mean } \pm S D\end{array}$ \\
\hline$<2 \mathrm{~cm}$ & $67(60.9)$ & $16(14.5)$ & $83(75.4)$ & $38 \pm 15.7$ \\
$>2 \mathrm{~cm}$ & $23(20.9)$ & $4(3.6)$ & $27(24.5)$ & $37 \pm 13.2$ \\
\hline
\end{tabular}


Low TP prevalence in Turkish population. Seafood consumption is not as common in the Cappadocia region population as in the other parts of the world having water sources. It might also have a role in this low prevalence.

The TP prevalence obtained from dry skulls was always higher than those from living subjects. 3,22 Woo ${ }^{3}$ studied five series of adult skulls and reported the TP prevalence ranging 38 to $66.5 \%$. Gözil et al ${ }^{22}$ investigated 80 dry skulls, and reported a high prevalence $(45.4 \%)$ of TP in Turkish population. This high prevalence may be due to a detailed and easy examination of dry skulls in terms of TP.

In the present study, the TP prevalence was significantly higher in females $(5.7 \%)$ than in males $(1.8 \%)(P<.001)$. Singaporean study is the only study that shows the same frequency of TP in both sexes. ${ }^{20}$ The findings of our study that the prevalence of TP was higher in females than in males is consistent with other studies. 3,4,6,7,9,11,13$15,18,19,21,23,26,27$ There is no certain explanation for this difference, but genetics may be suggested as a major factor.

Earlier studies,3,13,17 revealed higher TP prevalences during the second and third decades of life, whereas in our present study, it was higher during the sixth decade. The high prevalence of TP among the 60 years and older age group in our study should not be taken into consideration as an important finding because the sample of that age group is not large and might not reflect the true prevalence.

In our study, most of TP was smaller than 2 $\mathrm{cm}(75.4 \%)$, and located in premolar-molar area (66.4\%). Yildiz et $\mathrm{al}^{26}$ reported that $91.5 \%$ of TP smaller than $2 \mathrm{~cm}$, and $62 \%$ located in molar area in 5-15 age group. King and More ${ }^{31}$ who studied 400 individuals from the United States and United Kingdom reported that $67 \%$ of TP smaller than $2 \mathrm{~cm}$. However, Hashim et $\mathrm{a}^{32}$ revealed that the prevalence of TP larger than $2 \mathrm{~cm}$ was much greater than that of smaller. As Hashim et $\mathrm{al}^{32}$ studied groups from the Malaysian ethnic group; it is possible that size may be associated with ethnicity.

Most of the studies, 2,17,24,33,34 in agreement with the present study, showed that flat TP is the most common type, but Reichart et $\mathrm{al}^{8}$ and Jainkittivong

Table 4. Distribution of TP location in relation to age.

\begin{tabular}{lccccc}
\hline \multirow{2}{*}{$\begin{array}{l}\text { Age groups } \\
\text { lyears) }\end{array}$} & I-P region & P region & P-M region & M region & I-P-M region \\
\cline { 2 - 6 } & $\mathrm{n}(\%)$ & $\mathrm{n}(\%)$ & $\mathrm{n}(\%)$ & $\mathrm{n}(\%)$ & $\mathrm{n}(\%)$ \\
\hline $13-19$ & $0(0.0)$ & $1(0.9)$ & $6(5.4)$ & $4(3.6)$ & $0(0.0)$ \\
$20-29$ & $0(0.0)$ & $3(2.7)$ & $16(14.5)$ & $4(3.6)$ & $0(0.0)$ \\
$30-39$ & $1(0.9)$ & $5(4.5)$ & $20(18.1)$ & $4(3.6)$ & $3(2.7)$ \\
$40-49$ & $0(0.0)$ & $4(3.6)$ & $14(12.7)$ & $2(1.8)$ & $0(0.0)$ \\
$50-59$ & $0(0.0)$ & $1(0.9)$ & $8(7.2)$ & $2(1.8)$ & $1(0.9)$ \\
$\geq 60$ & $0(0.0)$ & $1(0.9)$ & $9(8.2)$ & $1(0.9)$ & $0(0.0)$ \\
Total & $1(0.9)$ & $15(13.6)$ & $73(66.4)$ & $17(15.4)$ & $4(3.6)$ \\
\hline
\end{tabular}

I: incisors; P: premolar; M: molar.

Table 5. Distribution of TP shape in relation to gender.

\begin{tabular}{lccc}
\hline TP shape & Females & Males & Total \\
& $\mathrm{n}(\%)$ & $\mathrm{n}(\%)$ & $\mathrm{n}(\%)$ \\
\hline Flat & $56(50.9)$ & $13(11.8)$ & $69(62.7)$ \\
Spindle & $33(30)$ & $7(6.3)$ & $40(36.3)$ \\
Nodular & $1(0.9)$ & $0(0.0)$ & $1(0.9)$ \\
Lobular & $0(0.0)$ & $0(0.0)$ & $0(0.0)$ \\
\hline
\end{tabular}


et al's ${ }^{4}$ studies reported spindle TP. It may suggest that ethnic differences in terms of TP shape do exist or not need further investigations.

\section{CONCLUSIONS}

The prevalence of TP in our sample was low in comparison to other Turkish population. Our results showed a significant relationship between the occurrence of TP and gender. The age and gender related differences with the size of TP were not noted. Most TP were found in flat shape (62.7\%), smaller than $2 \mathrm{~cm}(75.4 \%)$ and located at premolar-molar region $(66.4 \%)$. According to the literature, it was firstly showed that flat TP was the most common type in our large population. The present study supports that the etiology of TP are a combination of multifactorial genetic and environmental factors.

\section{ACKNOWLEDGMENTS}

This study was supported by The Scientific Research Committee of Erciyes University with the project grant number DHA-07-03.

\section{REFERENCES}

1. Regezi JA, Sciubba JJ. Oral pathology. Clinico-pathologic correlations. Philadelphia: WB Saunders, 1994:376-378.

2. Vidic B. Incidence of torus palatinus in Yugoslav skulls. $J$ Dent Res 1966;45:1511-1515.

3. Woo JK. Torus palatinus. Am J Phys Anthropol 1950;8:81111.

4. Jainkittivong A, Apinhasmit W, Swasdison S. Prevalence and clinical characteristics of oral tori in 1,520 Chulalongkorn University Dental School patients. Surg Radiol Anat 2007;29:125-131.

5. Thoma KH, Goldman HM. Oral pathology. St Louis: Mosby, 1960:1241-1247.

6. Eggen S, Natvig B, Gasemyr J. Variation in torus palatinus prevalence in Norway. Scand J Dent Res 1994;102:54-59.

7. Haugen LK. Palatine and mandibular tori. A morphologic study in the current Norwegian population. Acta Odontol Scand 1992;50:65-77.

8. Reichart PA, Neuhaus F, Sookasem M. Prevalence of torus palatinus and torus mandibularis in Germans and Thai. Community Dent Oral Epidemiol 1988;16:61-64.

9. Gorsky M, Bukai A, Shohat M. Genetic influence on the prevalence of torus palatinus. Am J Med Genet 1998;75:138140.
10. Neville BW, Damn DD, Allen CM, Bouquot JE. Oral and maxillofacial pathology, 2nd ed. Philadelphia: WB Saunders, 2002;20-21.

11. Tran KT, Shannon M. Images in clinical medicine. Torus palatinus. N Engl J Med 2007;356:1759.

12. King DR, Moore GE. The prevalence of torus palatinus. $J$ Oral Med 1971;26:113-115.

13. Apinhasmit W, Jainkittivong A, Swasdison S. Torus palatinus and torus mandibularis in a Thai population. $S c i$ Asia 2002;28:105-111.

14. Al Quran FA, Al-Dwairi ZN. Torus palatinus and torus mandibularis in edentulous patients. $J$ Contemp Dent Pract 2006;7:112-119

15. Al-Bayaty HF, Murti PR, Matthews R, Gupta PC. An epidemiological study of tori among 667 dental outpatients in Trinidad \& Tobago, West Indies. Int Dent $J$ 2001;51:300304.

16. Axelsson G, Hedegaard B. Torus palatinus in Icelandic schoolchildren. Am J Phys Anthropol 1985;67:105-112.

17. Bernaba JM. Morphology and incidence of torus palatinus and mandibularis in Brazilian Indians. $J$ Dent Res 1977;56:499-501.

18. Bruce I, Ndanu TA, Addo ME. Epidemiological aspects of oral tori in a Ghanaian community. Int Dent $J$ 2004;54:7882.

19. Cagirankaya LB, Kansu O, Hatipoglu MG. Is torus palatinus a feature of a well-developed maxilla. Clin Anat 2004;17:623625.

20. Chew $\mathrm{CL}$, Tan PH. Torus palatinus. A clinical study. Aust Dent $J$ 1984;29:245-248.

21. Gorsky M, Raviv M, Kfir E, Moskona D. Prevalence of torus palatinus in a population of young and adult Israelis. Arch Oral Biol 1996;41:623-625.

22. Gözil R, Sakul U, Calgüner E, Uz A. Morphometry of the hard palate and shapes of palatine torus and transvers palatine suture. T Klin Diş Hek Bil 1999;5:149-153.

23. Kerdpon D, Sirirungrojying S. A clinical study of oral tori in southern Thailand: prevalence and the relation to parafunctional activity. Eur J Oral Sci 1999;107:9-13.

24. Kolas S, Halperin V, Jefferis K, Huddleston S, Robinson HB. The occurrence of torus palatine and torus mandibularis in 2478 dental patients. Oral Surg Oral Med Oral Pathol 1953;6:1134-1141

25. Salem G, Holm SA, Fattah R, Basset S, Nasser C. Developmental oral anomalies among schoolchildren in Gizan region, Saudi Arabia. Community Dent Oral Epidemiol 1987;15:150-151.

26. Yildiz E, Deniz M, Ceyhan O. Prevalence of torus palatinus in Turkish Schoolchildren. Surg Radiol Anat 2005;27:368371 
27. Witkop CJ Jr, Barros L. Oral and genetic studies of Chileans, 1960. I. Oral anomalies. Am J Phys Anthropol 1963;21:1524.

28. Chohayeb AA, Volpe AR. Occurrence of torus palatinus and mandibularis among women of different ethnic groups. $\mathrm{Am}$ J Dent 2001;14:278-280.

29. Eggen S, Natvig B. Relationship between torus mandibularis and number of present teeth. Scand J Dent Res 1986;94:233240.

30. Belsky JL, Hamer JS, Hubert JE, Insogna K, Johns W. Torus palatinus: a new anatomical correlations with bone density in postmenopausal women. J Clin Endocrinol Metab 2003;88:2081-2086.

31. King DR, Moore GE. An analysis of torus palatinus in a transatlantic study. J Oral Med 1976;31:44-46.

32. Hashim Y, Haidar T, Kalsom I. The prevalence of oral tori in Malaysians. J Oral Med 1983;38:40-42.

33. Austin JE, Radford GH, Banks SO. Palatal and mandibular tori in the Negro. N Y State Dent J 1965;31:187-191.

34. Schaumann BF, Peagler FD, Gorlin RJ. Minor craniofacial anomalies among a Negro population. I. Prevalence of cleft uvula, commissural lip pits, preauricular pits, torus palatinus, and torus mandibularis. Oral Surg Oral Med Oral Pathol 1970;29:566-575. 